Informatika i sistemy upravleniya. - 2018. - No. 3(57). - P. 104-114.

Kuzmenko A.A. (aakuzmenko@sfedu.ru)

Southern federal University

\title{
ADAPTIVE CONTROLOF ELECTRIC VEHICLE WHEEL SLIP
}

The paper presents the application of the high-order integral adaptation principle and synergetic observer to design an adaptive law of electric vehicle wheel slip control. The control laws have simple structure and are focused on the use of physically measurable brake system variables.

Keywords: wheel slip, tire traction estimation, adaptive control, synergetic control theory, invariant, integral adaptation, synergetic observer.

DOI:10.22250/isu.2018.57.104-114

For citation:

Kuzmenko A.A. ADAPTIVE CONTROLOF ELECTRIC VEHICLE WHEEL SLIP // Informatika i sistemy upravleniya. - 2018. - No. 3(57). - P. 104-114. 